\title{
THE MODIFYING EFFECTS OF BACTERIAL SUBSTANCES IN THE COURSE OF INFECTION WITH NEUROTROPIC VIRUS
}

\section{REPORT, AN EXPLORATORY EXPERIMENT (I)}

\author{
MASAHIRO NAKAMURA AND YOH NAKAGAWA \\ Department of Microbiology, Kurume University, School \\ of Medicine, Kurume-shi, Japan
}

The investigation of Shope (1) concerning the etiology of the swine influenza may be the first experiment on the interaction between a virus and a bacterium. Shope discovered that the disease was caused by a symbiosis of the bacillus, $H$. influenzae suis, and a virus, i.e, the bacillus alone would not produce the disease; the virus alone produced an extremely mild, but spontaneously transmissible infection. Both agents were needed to reproduce the clinical syndrome. Horsfall and McCarty (2) reported a study on the effects of inoculating mice with both a virus and a bacterium in the course of investigations concerned with problems relative to the pathogenesis of primary atypical pneumonia. They considered that, when the first experiments were carried out, either of two possible results might develop; first, that streptococcus MG would have no discernible influence on the course of an infection induced by pneumonia virus of mice (PVM); or second, that it might, by contributing to the establishment of a complex infection, cause the results to be more severe than those of infections induced by PVM alone. However they found that, surprisingly, neither possibility evolved; instead, the inoculation of streptococcus $M G$ in mice which previously had been inoculated with PVM resulted in a distinctly less severe infection. After investigating on this unexpected finding in detail, they obtained certain polysaccharide preparations derived from various bacterial species, as well as similar materials from various origins other than bacteria, as agents of the modifying effect in the course of infection with PVM. Thereafter, they (3) (4) (5) (6) (7) studied on the inhibitory effect of polysaccharide derived from the bacterial origins on mumps virus multiplication. Volkert, Pierce, Horsfall, and Dubos (8) showed that following infection with small amounts of either PVM or influenza A virus (PR 8) intranasally, tuberculous lesions in the lungs of mice developed more rapidly and became more extensive than in control animals infected only with tubercle bacilli.

Recently, Buddingh (9) reported that combinated viral and bacterial infection established by intra-amniotic inoculation with influenza $C$ virus on the 14th followed 
by $H$. influenzae, type $b$, brought about a significant increase in the incidence and severity of disease manifestations in the embryos, and that there seemed to be relatively little or no effect on influenza $\mathrm{C}$ virus by the accompanying proliferation of $H$. influenzae, and finally that the exact nature of the virus-induced influences which enhanced the pathogenicity of the bacteria and favored the establishment of the infectious process under these circumstances remained to be determined. Stone (10) (11) expressed that, receiving suggestions from Hirst's discovery of the phenomenon of hemagglutination by influenza virus (12) and of being a somewhat similar reaction between this virus and cells of the excised ferret lung (13), infection by influenza viruses of embryonated eggs after allantoic inoculation, and of mouse lungs after intranasal instillation, could be prevented by pretreatment of the exposed cells with the receptor-destroying enzyme ( $\mathrm{RDE}$ ) of V. cholerae (14). Cairns (15) demonstrated also that death of mice from infection by a neurotropic variant of influenza virus could be similarly prevented following an intracerebral injection of RDE.

The results obtained by seniors mentioned above, however, are that of relationships between pneumotropic viruses and bacteria, and at present there is very few studies on the interaction between neurotropic viruses and bacteria. Goto and others (16) (17) and Hayashi and others (18) reported some detail experiments on the inhibitory effects of bacterial polysaccharide in the course of infection with Japanese B encephalitis virus. Nakagawa and Yoshida (19) described an experiment on the neurotropic virus-bacteria relationship in which the infection with the GDVII strain of mouse encephalomyelitis virus was prevented by pretreatment of RDE produced from V. cholerae culture filtrate.

The purpose of this paper is to report a part of an exploratory experiment to ascertain the presence or absence of similar modifying effect of bacteria or bacterial substances on the course of neurotropic virus infection to that of pneumotopic virus in the natural state.

\section{MATERIALS ANI METHODS}

Virus. The GDVII strain of mouse encephalomyelitis virus which has been maintained by serial passage in adult mice in this laboratory was employed.

Bacteria. The following bacteria which have been maintained in this laboratory were tested.

Cocci: Staphylococcus aureus (209 P strain), albus, and citreus; Sarcina lutea; Streptococcus hemolyticus, viridans, and nonhemolyticus; Diplococcus pneumoniae I-type. 
Gram-negative bacilli: H. pertussis, Proteus OX 19, Brucella abortus Bang, E. coli (B Strain) S. typhi, Shigella dysenteriae, S. cholerae suis (1348 Strain), V. cholerae I (Inaba Strain), II (Ogawa-Strain).

Gram-positive bacillus: Myc. smegmatis.

Streptococci, Dipl. pneumoniae and H. pertussis which were grown in serumbroth at $37^{\circ} \mathrm{C}$ for 24 hours, Myc. smegmatis which was grown in $3 \%$ glycerine broth at $37^{\circ} \mathrm{C}$ for three days, Vibrio which was grown in alkali broth and others which were grown in broth (pH7.0-7.2) at 37 for 24 hours were used.

Procedure in general. Groups of 3-4 weeks old mice were administrated intranasally with cultured bacteria mentioned above, in approximatly $0.03 \mathrm{ml}$ two days, and one hour before and two days after, respectively, inoculation with dilutions of GDVII virus by intranasal route under the aether anesthesia. The effect of bacteria on the course of virus infection was estimated by the degree of reduction or increase in the $\mathrm{LD}_{50}$ of the experimental group from the level found in a comparable group of mice which had received with sterile broth.

\section{EXPERIMENTAI.}

Effects of Staphylococci. The results obtained are summerized in Table 1. Staphylococci which were administrated before virus inoculation showed the inhibitory

TABLE 1

Effects of intranasal inoculation of Staphylococci on the results of GDVII virus titrations in mice

\begin{tabular}{|c|c|c|c|c|}
\hline First inoculation I. N.* & Interval & Second inoculation I. N & $\begin{array}{l}-\log \\
\text { LDะo }\end{array}$ & $\begin{array}{l}\text { Log. } \\
\text { diff. }\end{array}$ \\
\hline 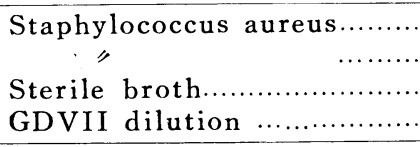 & $\begin{array}{l}2 \mathrm{ds} \\
1 \mathrm{~h} \\
1 \mathrm{~h} \\
2 \mathrm{ds}\end{array}$ & $\begin{array}{c}\text { GDVII dilution } \\
" \\
\text { " } \\
\text { Staphyloccus aureus }\end{array}$ & $\begin{array}{l}2.51 \\
2.26 \\
2.83 \\
3.57\end{array}$ & $\begin{array}{l}-0.32 \\
-0.57 \\
+0.74 \\
\end{array}$ \\
\hline $\begin{array}{l}\text { Staphylococcus albus } \ldots \ldots \ldots \\
\quad \ldots \ldots \ldots \ldots \\
\text { Sterile broth } \ldots \ldots \ldots \ldots \ldots \ldots \ldots \\
\text { GDVII dilution } \ldots \ldots \ldots \ldots \ldots \ldots \ldots\end{array}$ & $\begin{array}{l}2 \mathrm{ds} \\
1 \mathrm{~h} \\
1 \mathrm{~h} \\
2 \mathrm{ds}\end{array}$ & $\begin{array}{c}\text { GDVII dilution } \\
\text { " } \\
\text { Staphyococcus albus }\end{array}$ & $\begin{array}{l}2.62 \\
3.16 \\
3.57 \\
3.77\end{array}$ & $\begin{array}{l}-0.95 \\
-0.41 \\
+0.20\end{array}$ \\
\hline 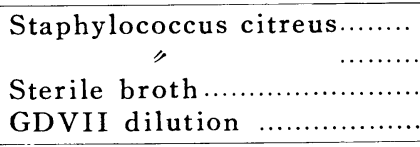 & $\begin{array}{l}2 \mathrm{ds} \\
1 \mathrm{~h} \\
1 \mathrm{~h} \\
2 \mathrm{ds}\end{array}$ & $\begin{array}{c}\text { GDVII dilution } \\
\text { " } \\
\text { Staphylococcus citreus }\end{array}$ & $\begin{array}{l}3.22 \\
2.83 \\
3.00 \\
2.68\end{array}$ & $\begin{array}{l}+0.22 \\
-0.17 \\
-0.32\end{array}$ \\
\hline 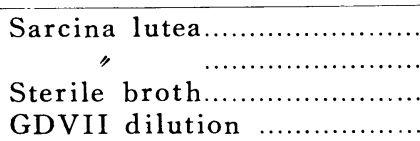 & $\begin{array}{l}2 \mathrm{ds} \\
1 \mathrm{~h} \\
1 \mathrm{~h} \\
2 \mathrm{ds}\end{array}$ & $\begin{array}{c}\text { GDVII dilution } \\
\text { " } \\
\text { Sarcina lutea }\end{array}$ & $\begin{array}{r}>4.00 \\
3.37 \\
2.68 \\
3.50\end{array}$ & $\begin{array}{r}>+1.32 \\
+0.69 \\
+0.62\end{array}$ \\
\hline
\end{tabular}

* I.N.=intranasal. 
effect, but except staphylococcus citreus, staphylococci after virus inoculation had the stimulating effect in the course of virus infection. On the contrary, Sarcina lutea had the stimulating effect, particularly in the case of administration before 2 days of virus inoculation.

Effect of Streptococci.

Streptococci are more stimulatory than staphylococci on the course of virus infection, particularly in the case of administration after virus inoculation (Table 2).

TABLE 2

Effects of intranasal inoculation of Streptococci on the results

of GDVII virus titrations in mice

\begin{tabular}{|c|c|c|c|c|}
\hline First inoculation I. N. & $\begin{array}{l}\text { Inter- } \\
\text { val }\end{array}$ & Second inoculation I. N, & \multicolumn{2}{|c|}{$-\log$ LD:s Log. diff } \\
\hline Streptococcus hemolyticus... & $2 \mathrm{ds}$ & GDVII dilution & 3.33 & +0.33 \\
\hline$"$ & $1 \mathrm{~h}$ & $"$ & 3.49 & +0.49 \\
\hline Sterile serum broth & $1 \mathrm{~h}$ & " & 3.00 & \\
\hline GDVII dilution .... & $2 \mathrm{ds}$ & Streptococcus hemolyticus & 3.62 & +0.62 \\
\hline Streptococcus viridans........ & $2 \mathrm{ds}$ & GDVII dilution & 2.31 & -0.43 \\
\hline$"$ & $1 \mathrm{~h}$ & " & 3.79 & +1.05 \\
\hline Sterile serum broth & $1 \mathrm{~h}$ & " & 2.74 & \\
\hline GDVII dilution ...... & $2 \mathrm{ds}$ & Streptococcus viridans & $>4.00$ & $>+1.26$ \\
\hline Streptococcus nonhemolyticus & $2 \mathrm{ds}$ & GDVII dilution & 3.15 & +0.15 \\
\hline$"$ & $1 \mathrm{~h}$ & " & 2.49 & -0.51 \\
\hline Sterile serum broth & $1 \mathrm{~h}$ & $"$ & 3.00 & \\
\hline GDVII dilution $\ldots$ & $2 \mathrm{ds}$ & Streptococcus nonhemolyticus & 3.14 & +0.14 \\
\hline
\end{tabular}

Effect of Diplococcus pneumoniae and H. pertussis.

Administration of Dipl. pneumoniae I type before and after virus inoculation made to increase the $\mathrm{LD}_{50}$ for mice.

On the contrary, H. pertussis has an inhibitory effect on the course of virus infection both before and after virus inoculation. The log. difference in the $\mathrm{LD}_{50}$ for the treated mice as compared to the controls was $-1.49 \log \mathrm{LD}_{50}$. This effect of $\mathrm{H}$. pertussis will be noted (Table 3 ).

Effect of E. coli, Salmonella and Shigella.

The results obtained were shown in Table 4 . It will be found here that among the tested bacteria, one has stimulating or another has inhibitory effects on the course of GDVII infection. The former includes S. cholerae suis and the latter includes E. coli and Shigella. When S. cholerae suis was given to the mice before or after the virus, $\mathrm{LD}_{50}$ titers were much higher than those of controls, on the other 
TABLE 3

Effects of inlranasal inoculation of Dipl. pneumoniae and $H$. pertussis on the results of GDVII virus titrations in mice

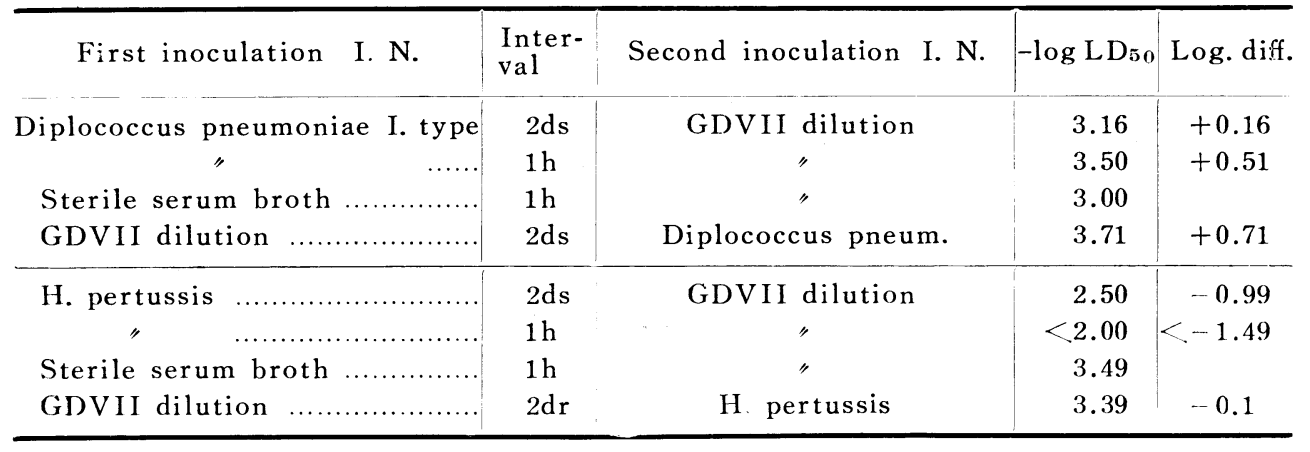

hand, the $\log$ difference of $\mathrm{LD}_{50}$ for mice pretreated by $\mathrm{E}$. coli as compared to the controls was-1.54. Therefore, both strains, S. cholerae suis and E. coli will be selected for the further experiments as the materials having stimulating effect and inhibitory effect respectively on the course of virus infection.

Though S. typhi murium was tested, the deta obtained were excepted from those

TABLE 4

Effects of intranasal inoculation of E. coli, Shigella and Salmonella on the resulls of GDVII virus titrations in mice

\begin{tabular}{|c|c|c|c|c|}
\hline First inoculation I. N. & $\begin{array}{l}\text { Inter- } \\
\text { val }\end{array}$ & Second inoculation I. N. & $-\log \mathrm{LD} \mathrm{D}_{\boldsymbol{5}}$ & Log diff. \\
\hline E. soli .... & $2 \mathrm{ds}$ & GDVII dilution & 2.00 & -1.54 \\
\hline$"$ & $1 \mathrm{~h}$ & " & 2.22 & -1.32 \\
\hline Sterile broth ...... & $1 \mathrm{~h}$ & " & 3.54 & \\
\hline GDVII dilution ....... & $2 \mathrm{ds}$ & E. coli & 3.49 & -0.05 \\
\hline S. typhi & $2 \mathrm{ds}$ & GDVII dilution & 3.26 & +0.52 \\
\hline$" \quad \ldots .$. & $1 \mathrm{~h}$ & " & 3.00 & +0.26 \\
\hline Sterile broth. & $1 \mathrm{~h}$ & " & 2.74 & \\
\hline GDVII dilution ..... & $2 \mathrm{ds}$ & S typhi & $>4.00$ & $>+1.26$ \\
\hline Shigella dysenteriae & $2 \mathrm{ds}$ & GDVII dilution & $<2.00$ & $<-1.38$ \\
\hline " & $1 \mathrm{~h}$ & " & 3.33 & -0.05 \\
\hline Steri!e broth & $1 \mathrm{~h}$ & " & 3.38 & \\
\hline GDVII dilution ... & $1 \mathrm{ds}$ & Shigella dysenteriae & 3.87 & +0.49 \\
\hline S. cholerae suis & $2 \mathrm{ds}$ & GDVII dilution & $>4.00$ & $>+0.62$ \\
\hline " & $1 \mathrm{~h}$ & " & $>4.00$ & $>+0.62$ \\
\hline Sterile broth........ & $1 \mathrm{~h}$ & " & 3.38 & \\
\hline GDVII dilution ... & $2 \mathrm{ds}$ & $\mathrm{S}$ cholerae suis & $>4.00$ & $>+0.62$ \\
\hline
\end{tabular}


of the serial experiments, because, needless to say, this bacterium alone killed the mice. The interference phenomenon between this strain and the virus was not recognized.

Effect of $V$. cholerae.

The administration of $\mathrm{V}$. cholerae both before and after virus inoculation was to indicate the inhibitory effect. It will be presumed that one of these inhibitory mechanism might be attributed to preventing the connection of virus to the susceptible cells. Considering the GDVII virus is one of the viruses capable of hemagglutionation, the assumption will not be unreasonable. The fact that the virus infection

TABLE 5

Effects of intranasal inoculation of Vibrio on the results of GDVII virus titrations in mice

\begin{tabular}{|c|c|c|c|c|}
\hline First inoculation I. N. & $\begin{array}{l}\text { Inter- } \\
\text { val }\end{array}$ & Second inoculation I. N. & $\left|-\log \mathrm{LD}_{50}\right|$ & Log. diff. \\
\hline V. cholerae I. type & $2 \mathrm{ds}$ & GDVII dilution & 3.24 & -0.24 \\
\hline " & $1 \mathrm{~h}$ & " & 3.10 & -0.38 \\
\hline Sterile alkali broth & $1 \mathrm{~h}$ & " & 3.48 & \\
\hline GDVII dilution $\ldots . .$. & $2 \mathrm{ds}$ & V. cholerae I type & 2.24 & -1.24 \\
\hline V. cholerae II. type. & $2 \mathrm{ds}$ & GDVII dilution & 1.74 & -1.50 \\
\hline " & $1 \mathrm{~h}$ & " & 2.83 & -0.41 \\
\hline Sterile alkali broth & $1 \mathrm{~h}$ & " & 3.24 & \\
\hline GDVII dilution ...... & $2 \mathrm{ds}$ & V cholerae II type & 2.74 & -0.50 \\
\hline
\end{tabular}

TABLE 6

Effect of intranasal inoculation of misellaneous bacteria on the results of GDVII virus titrations in mice

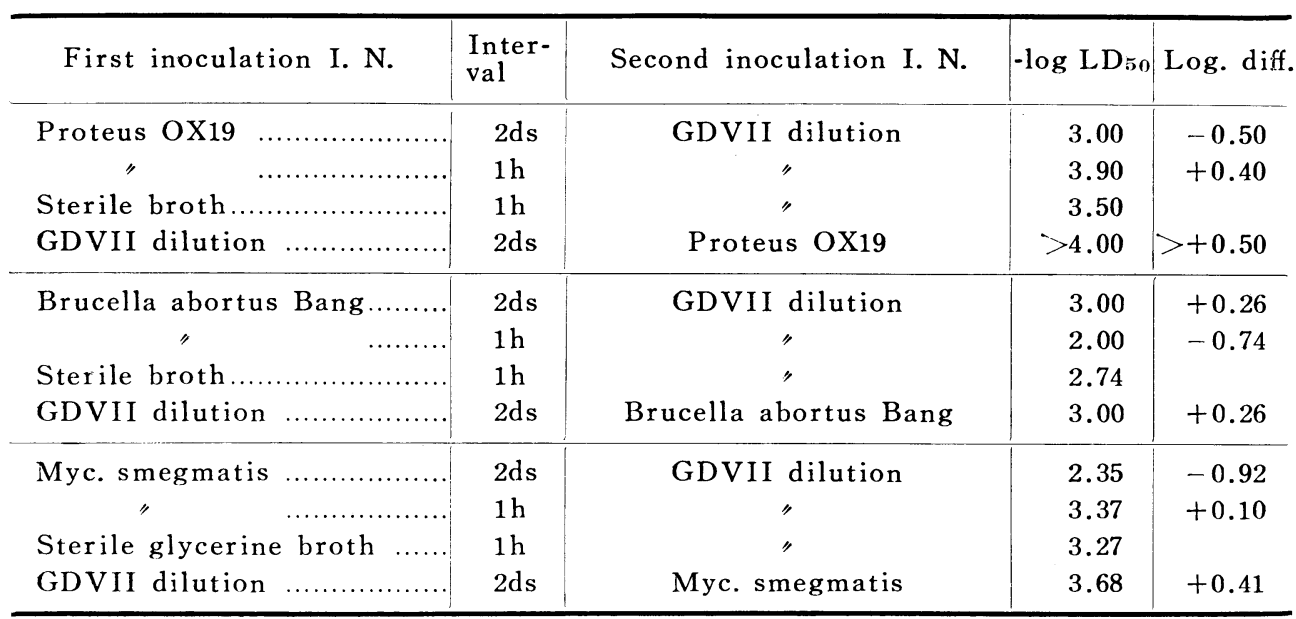


was inhibited by the administration of V. cholerae after 2 days of virus, will be noted for the following experiment (Table 5).

Effect of miscellaneous bacteria.

Proteus OX 19, Brucella abortus Bang, and Mycobacterium smegmatis had no significat effect on the course of GDVII infection (Table 6).

\section{DISCUSSION}

As no inactivation of the GDVII strain of mouse encephalomyelitis virus by treatment with ether for not a longer period was demonstrated in the separated report (20), the experiment of infection of GDVII under ether anesthesia is not as considerable for the inactivation of the virus as in the case of western and eastern equine encephalitis virus (21).

Since the purpose of this paper is to research the modifying effect of bacteria on the course of neurotropic virus infection in the natural state, in an exploratory experiment, the virus and bacteria inoculation by intranasal route were employed. The experiment of Pearson (22) on the chemical inhibitors of the GDVII virus by tissue culture method seems different from the purpose of this study.

The data obtained in the exploratory experiment demonstrated that a definite relationships between the kinds of bacteria and the modifying effect on virus infection were not found. However, it is obvious that there are some bacteria having stimulating or inhibitory effect on the course of neurotropic virus infection. In the former, Sarcina lutea and S. cholerae suis might be estimated, and in the latter E. coli, $\mathrm{H}$. pertussis, and V. cholerae might be noted, if the log. difference 1.0 or more should be recognized as the significant value.

The nature of the mechanism of the modifying effect of bacteria on the course of the infection with neurotropic virus would be clarified in the extensive experiments, but it might be thought that the significant inhibitory effect of $V$. cholerae would depend upon the RDE which was produced by this bacteria.

Luria (23) described two possiblities concerning discovery of virus inactivation and chemotherapy that (1) success might depend on the discovery of enzyme systems, either carried by the host cell or possibly by the virus itself, whose suppression would be tolerated by the host but not by the virus, and (2) another possible line of approach to virus chemotherapy stems from the discovery of specific organic inhibitors of virus adsorption onto susceptible cells.

Horsfall and others (7) described in the discussion on the modifying effect of bacterial polysaccharide which they derived on the course of the mumps infection, that 
the nature of the effect could affect to either one of four steps in the process of viral multiplication which in theory could be supposed: (1) Polysaccharide might prevent virus-cell combination; (2) Polysaccharide might prevent invasion or penetration of the cell by virus; (3) Polysaccharide might prevent release of virus from the infected cell after multiplication occurs; (4) Polysaccharide may block or compete with an intracellular process which is required by the virus during multiplication. Moreover, they presumed that the bacterial polyssaccharide might affect to the cellular metabolic step, because the inhibition with mumps virus as with PVM was obtained after the viral concentration has reached a level high enough to indicate that almost all susceptible cells were already infected. Goto (24) also discussed in detail on the mechanism of inhibitory effect of bacterial polysaccharide to the infection with Japanese B encephalitis virus.

It may be probable to express from the data obtained in the present paper that one of the mechanisms of the modifying effect of various bacteria on the neurotropic viral infection could affect to the metabolism of susceptible cells at the site of viral infection, because the ability of production of RDE was not reported in various bacteria, except V. cholerae may be in fact due to prevention of virus-cell combination as suggesting the report of Nakagawa and Yoshida (19).

Therefore, the studies on the modifying effect of bacteria or bacterial substances in the course of infections with neurotropic virus will contribute toward the information to the mechanism of virus multiplication; for instance, it could be presumed that the bacteria or bacterial substances might affect to the susceptible cells as a metabolic substrate, and might convert the developing viral growth to the incomplete growth.

In research of plant virus, Takahashi (25) reported the study on the polysaccharide derived from yeast which could inactivate the tabacco mosic virus.

Finally, it will be considered that the stimulating effect of bacteria will activate or provoke the inapparent or latent virus infection, and will change the non-cytopathogenic virus to the cytopathogenic virus and that the inhibitory effect of bacteria will inactivate the virus infection, i. e, convert the apparent infection to inapparent infection, and will prevent the virus infection.

The bacteria which were not tested in this present experiment will be examined, in future, in the following experiments.

\section{SUMMARY}

As an experiment, the modifying effects of various bacteria on the course of 
infection with the GDVII strain of mouse encephalomyelitis virus were tested by observing the log. difference in the $\mathrm{LD}_{50}$ for the mice pretreated or post-treated by becteria as compared to the controls. The results obtained indicate that Sarcina lutea and $\mathrm{S}$. cholerae suis have stimulating effect of virus infection and E. coli, $\mathrm{H}$. pertussis, and V. cholerae have the inhibitory effect; E. coli, in particular. The nature of the mechanism of these effects will be clarified in the following extensive studies.

\section{REFERENCES}

1. Shope, R. E: Swine influenza, in virus diseases, Ithaca, N. Y. Cornell Univ. press, p. 84, 1943. (Zinsser' textbook of Bacteriology).

2. Horsfall, Jr. F. L. And Mc Carty, M.: The modifying effects of certain substances of bacterial origin on the course of infection with pneumonia virus of mice. J. Exp. Med., Vol. 85, 623-646, 1947.

3. Ginsberg, H. S., Goebel, W. F., and Horsfall, Jr. F. L.: The inhibitory effect of polysaccharide on mumps virus multiplication. J. Exp. Med. Vol. 87, 385-410, 1948.

4. Ginsberg. H. S., Goeberl, W. F. ani Horsfall, Jr, F. L.: The effect of polysaccharide on the reaction between erythrocytes and viruses, with particular reference to mumps virus. J. Exp. Med., Vol. 87, 411-424, 1948.

5. Ginsberg, H. S. and Horsfall, Jr. F. L.: Concurrent infection with influenza virus and mumps virus or pneumonia virus of mice (PVM) as bearing on the inhibition of virus multiplication by bacterial polysaccharides. J. Exp. Med., Vol. 89, 37-52, 1949.

6. Ginsberg, H. S. and Horsfall, Jr. F. L.: A resistant variant of mumps virus: multiplication of the presence of inhibitory quantities of Friedländer bacillus polysaccharide J. Exp. Med., Vol. 90, 393-407, 1949

7. Ginsberg, H. S., Goebel, W. F. and Horsfall, Jr. F. L.: Inhibition of mumps virus multiplication by a polysaccharide. P. S. E. B. M., Vol. 66, 99-100, 1947.

8. Volrert, M., Pierce, C, Horsfall, Jr. F. L. and Dubos, R. J.: The enhancing effect of concurrent infection with pneumotropic viruses on pulmonary tuberculosis in mice. J. Exp. Med., Vol. 86, 203-214, 1947.

9. Buddingh. G, J.: Exprimental combined viral and bacterial infection in embryonated eggs. J. Exp. Med., Vol. 104, 947-958, 1956.

10. Stone, J. D.: Prevention of virus infection with enzyme of V. cholerae. I. Studies with viruses of mumps-influenzae group in chick embryos. Austral. J. Exp. Biol. Vol. 26, 49-64, 1948.

11. Stone, J. D.: Prevention of virus infection with enzyme of V. cholerae. II. Studies with influenza virus in mice. Austral. J. Exp. Med., Vol. 26, 287-298, 1948. 
12. Hirst, G. K.: The agglutination of red cells by allantoic fluid of chick embryos infected with influenza virus. Science, Vol. 94, 22-23, 1941.

13. Hirst, C. K.: Adsorption of influenza virus on cells of the respiratory track. J. Exp. Med., Vol. 78, 99-109 1943.

14. BURnet, F. M.: The initiation of cellular infection by influenza and related viruses. Lancet, Vol. 254, 7-11, 1948.

15. Cairns, H. J. F.: Protetion by receptor destroying enzyme against infection with a neurotropic variant of influenza virus. Nature, No. 4269, 335, 1951.

16. Gото, M. et al: Influence of pneumococcal capsular polysaccharides on the experimental Japanese B encephalitis virus infection. Tokyo Univ. Ricchi-Shizen-Kagaku -Ken. Report, No. 19, 60-68, 1952 (in Japanese).

17. Gото, M. et al: Experimental chemotherapy on the virus encephalitis. Seitai-noKagaku, Vol. 2, 2-7, 1950 (in Japanese).

18. HAYASH, T. et al: On the bacterial polysaccharides (3 report). Sai-shin-Igaku, Vol. 9, $867-862,1954$ (in Japanese).

19. Nakagawa, Y. and Yoshida, S.: Influence of RDE on the infection with neurotropic virus. J. Kurume Med. Ass., Vol. 19, 783-787, 1956 (in Japanese).

20. Nakagaida, Y. and Nakamura, M,: Purification and concentration of GDVII strain of mouse encephalomyelitis virus by means of ether extraction, hemagglutination, and methanol and acetone precipitation. I. Report. Kurume Med. J., Vol. 2, 32-41, 1955.

21. Sulkin, E., Zarafonetis, C. and Goth, A.: Influence of anesthesia on experimental neurotropic virus infections. J. Exp. Med., Vol. 84, 277-292, 1946.

22. Pearson, H. E., Lagerborg, D. L. and Visser, D. W.: Chemical inhibitors of Theiler's virus. P.S. E. B M., Vol. 93, 61-63, 1956.

23. Luria, S. E.: General virology. 144-146, 1953.

24. Goтo, M.: On the experimental chemotherapy on the virus infection. Sai-shin-Igaku, Vol. 8, 537-543, 1953 (in Japanese).

25. Takahashi, W. N.: Properties of a virus inactivator from yeast. Science, Vol. 104, $377,1946$. 